University for Business and Technology in Kosovo

UBT Knowledge Center

Oct 28th, 11:00 AM - 12:30 PM

\title{
Indication of Temperature and Time during Storage in Shelf Life of Pasteurized Milk, by using Response Surface Methodology
}

\author{
Alush Musaj \\ Universiteti of Mitrovica \\ Përparim Birinxhiku \\ Universiteti of Mitrovica \\ Bahtir Hyseni \\ Universiteti of Mitrovica, bahtir.hyseni@umib.net
}

Follow this and additional works at: https://knowledgecenter.ubt-uni.net/conference

Part of the Food Science Commons

\section{Recommended Citation}

Musaj, Alush; Birinxhiku, Përparim; and Hyseni, Bahtir, "Indication of Temperature and Time during Storage in Shelf Life of Pasteurized Milk, by using Response Surface Methodology" (2017). UBT International Conference. 167.

https://knowledgecenter.ubt-uni.net/conference/2017/all-events/167

This Event is brought to you for free and open access by the Publication and Journals at UBT Knowledge Center. It has been accepted for inclusion in UBT International Conference by an authorized administrator of UBT Knowledge Center. For more information, please contact knowledge.center@ubt-uni.net. 


\title{
Indication of Temperature and Time during Storage in Shelf Life of Pasteurized Milk. bv using Response Surface Methodology
}

\author{
Alush Musaj $^{1}$, Përparim Birinxhiku ${ }^{1}$, Bahtir Hyseni ${ }^{2}$ \\ ${ }^{1}$ Universiteti of Mitrovica, Food Technology Department, \\ 40000 Mitrovica, Kosovo \\ ${ }^{2}$ Yeditepe University, Graduated school of natural and applied sciences, \\ Istanbul, Turkey \\ Bahtir Hyseni, bahtir.hyseni@umib,net
}

\begin{abstract}
Milk is a complex food product, with a high nutritional value. Milk produced from healthy cow is considered to be sterile, even though this is highly dependent on the environment of farm. Milk is processed to bring a cured with extend shelf life product. Pasteurization, is a curing process for milk based on thermal treatment, this process mostly inhibit the microbial growth but it does not destroy total microorganisms. Consequently, its shelf life is dependent on the storage parameters as temperature and time. Hence, the aim of our study was to analyze and prove indication of temperature and time by using statistical method called Response Surface Methodology (RSM). Experiments are designed with to independent variable temperature and time while as dependent variable is considered the total number of microorganisms (standard plate count). Results showed that storage temperature is the main factor that can extend the shelf life of the product, while for the predication of the shelf life of the product by using build equation by RSM, remains to be seen in future studies.
\end{abstract}

Keywords: Pasteurization, Milk, RSM, Temperature

\section{INTRODUCTION}

Milk is considered to be an excellent food that provides major nutritional requirements to man at any age [1]. Pasteurization of milk is a middle thermal treatment of raw milk which include treatment of milk between $72-63^{\circ} \mathrm{C}$ for 15 "'-30', respectively. After pasteurization process milk should be packed and storage in refrigerator temperature until it reaches to consummator table. Pasteurized milk is more preferred for consummation and kitchen than UHT milk, because shows less losses in nutritional value, less thermal changes in organoleptic characteristics [2]. Furthermore, extended shelf life pasteurized milk is favorite product now compared with the conventionally one, due to high request of the market for products with prolonged shelf life. There are several techniques for producing extended shelf life milk high-heat treatment, high hydrostatic pressure, pulsed electric fields and microfiltration or bactofugation [3].

Microbial spoilage are responsible for food product losses, which has economical effect in food industry. Author Ranieri et al, reported that $20 \%$ of pasteurized milk produced in US is discarded for the reason of microbial spoilage. Bacillus and Paenibacillus reported to be problematic one, which cause spoilage of pasteurized milk. Accordingly to that, authors use real time PCR by specific TaqMan assay to identify psychrotolerant spore-forming of Paenibacillus spp. in raw and heat treated milk. Author reported that TaqMan assay make available to differentiate raw milk with the potential for lower post-pasteurization bacterial outgrowth [4]. 
Raw milk contamination from gram negative bacteria as result of poor hygienic practices in milking process and transport was reported by [5]. Although, in the same milk no gram negative bacteria was detected after pasteurization process. In contrast author Anderson et al [6] reported that majority of milk samples even though unexpired and pasteurized contained high levels of Enterobacter spp. and Escherichia coli, so they recommend that pasteurization process should be tested in each series for its effect.

Most of the time storage temperature of pasteurized milk is found to be abused, a slight abuse of storage temperature around $7^{\circ} \mathrm{C}$ resulted with more than $10^{5} \mathrm{CFU} / \mathrm{ml}$ Bacillus cereus and about $4 \%$ enterotoxin of B. cereus which could lead to foodborne illness while higher temperature of storage brought higher percentage of contamination [7].

A linear predictable model for Listeria monocytogenes growth in pasteurized milk was built in studies [8] based on temperature and time during transportation, retail storage, and domestic storage. The build model predicted that in around $44 \%$ of the packed milk L. monocytogenes will grow until the time of consumption, they also concluded that decrease of the storage temperature for $2^{\circ} \mathrm{C}$ will extend the shelf life for two days more. Same group of researchers published another article about dynamic model for growth of $L$. monocytogenes in commercial pasteurized milk. Build model predicted results with less than $10 \%$ mistake which is a good results considering that there was no standardization of the samples during model building [9].

\section{MATERIALS AND METHODS}

\section{Materials}

All materials that are used for medium preparation were from lab standard source, and all the work is done in aseptic way.

\section{Sampling}

Pasteurized commercial milk comes regularly to food markets every day in the morning. Milk that was used in this study was packed in the plastic bag of $1 \mathrm{~L}$. The shelf life of the milk recommended by producer was $48 \mathrm{~h}$ after the date of production which was printed in the bag. Samples were transport to the laboratory by cooler bag and storage to different temperatures for certain amount of time based in designed experiments. Each sample was analyzed for total number of colony and total number of coliforms.

\section{Experiment design}

Response Surface Methodology was used to design experiments, based on the number of independent variables that will be treated. Temperature and time of storage were used as independent variable, while as dependent variable number of total colony formed and number of total coliform was analyzed. According to the number of independent variables of the study the number of experiments that will be performed are calculated as below:

$$
\mathrm{N}=2 * \mathrm{n}+2^{\mathrm{n}}+\mathrm{n}=2 * 2+2^{2}+2=10
$$

Where, $\mathrm{N}$ - is number of experiments, $\mathrm{n}$ - is the number of independent variables. The highest values of experiments $53 \mathrm{~h}-20^{\circ} \mathrm{C}$, while the lowest ones are $20 \mathrm{~h}-2^{\circ} \mathrm{C}$ for time and temperature respectively. Below is given the table with the designed experiments which report for 4 star points, 4 factorial points and 2 center points [10]. 
Table 1 Designed experiments with time and temperature of storage as independent variable

\begin{tabular}{ccc}
\hline $\begin{array}{c}\text { No. } \\
\text { experiments }\end{array}$ & Storage time & Storage temperature \\
\hline $\mathbf{1}$ & 48 & 4 \\
$\mathbf{2}$ & 24 & 4 \\
$\mathbf{3}$ & 48 & 15 \\
$\mathbf{4}$ & 24 & 15 \\
$\mathbf{5}$ & 53 & 10 \\
$\mathbf{6}$ & 20 & 10 \\
$\mathbf{7}$ & 36 & 20 \\
$\mathbf{8}$ & 36 & 2 \\
$\mathbf{9}$ & 36 & 10 \\
$\mathbf{1 0}$ & 36 & 10 \\
\hline
\end{tabular}

\section{Spread plate technique for Total number of colony and total coliform}

For determination of total number of colony and total coliform spread plate technique was used as reported by [11]. Form each diluted sample $0.1 \mathrm{ml}$ were placed and spread in petri dish plate with Nutrient agar or Endo-Les agar-bose for total number of colony and total coliform, respectively. Samples were incubated at static incubator at $37^{\circ} \mathrm{C}$ for $48 \mathrm{~h}$. Samples are read and calculated by excel based on [10] for building a linear regression equation.

\section{RESULTS}

Using RSM ten experiments were designed for two independent variables. Both, total number of colony and total coliform were measured in petri dish plate by spreading techniques. Moreover, to decrease the probability of any random error and make results more confident each sample is done in triplicate. Results shown below in Table 2, are average of each triplicate results.

Table 2 Results for Total number of Colony and total coliform

\begin{tabular}{ccccc}
\hline No. experiments & Time & Temperature & $\begin{array}{c}\text { Total number of } \\
\text { colony cfu /ml }\end{array}$ & $\begin{array}{c}\text { Coliform } \\
\text { cfu/ml }\end{array}$ \\
\hline $\mathbf{1}$ & 48 & 4 & $29 * 10^{2}$ & 0 \\
$\mathbf{2}$ & 24 & 4 & $12^{*} 10^{2}$ & $3 * 10^{2}$ \\
$\mathbf{3}$ & 48 & 15 & $10^{*} 10^{4}$ & 0 \\
$\mathbf{4}$ & 24 & 15 & $78^{*} 10^{3}$ & 0 \\
$\mathbf{5}$ & 53 & 10 & $664^{*} 10^{4}$ & 0 \\
$\mathbf{6}$ & 20 & 10 & $446^{*} 10^{3}$ & 0 \\
$\mathbf{7}$ & 36 & 20 & $48^{*} 10^{4}$ & 0 \\
$\mathbf{8}$ & 36 & 2 & $258^{*} 10^{4}$ & 0 \\
$\mathbf{9}$ & 36 & 10 & $17^{*} 10^{2}$ & 0 \\
$\mathbf{1 0}$ & 36 & 10 & $12^{*} 10^{2}$ & 0 \\
\hline
\end{tabular}

$\mathrm{R}$ x64.3.3.3 free software was used to statistically analyze the data and also by the summarized data we build the equation where, as independent variable are time $\mathrm{x} 1$ and temperature $\mathrm{x} 2$ while $\mathrm{cfu} / \mathrm{ml}$ is dependent variable written by yobs. Below are shown how the data are calculated and the results in $\mathrm{R}$ code.

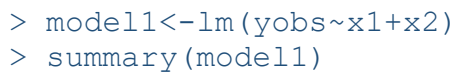


Call:

$\operatorname{lm}($ formula $=$ yobs $\sim \mathrm{x} 1+\mathrm{x} 2)$

$\begin{array}{lll}\text { Residuals: } & \\ \text { Min } & 1 \mathrm{Q} \text { Median } & \\ & & \end{array}$

$\begin{array}{lllll}-2459032 & -1022408 & -116392 & 800773 & 4023868\end{array}$

Coefficients

Estimate std. Error t value $\operatorname{Pr}(>|t|)$

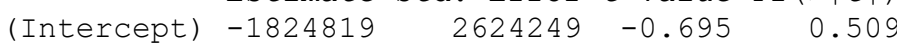

$\begin{array}{lllll}x 1 & 93671 & 61730 & 1.517 & 0.173\end{array}$

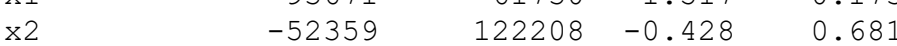

Residual standard error: 2067000 on 7 degrees of freedom

Multiple R-squared: 0.2621 , Adjusted R-squared: 0.05124

F-statistic: 1.243 on 2 and 7 DF, p-value: 0.3452

Intercept and two partial regression coefficients for time and temperature were shown from software in column Estimate. The build model is shown below

$$
y=-182.48 * 10^{4}+936.7 * 10^{2} x_{1}-523.59 * 10^{2} x_{2}
$$

Using $\mathrm{R}$ software $\mathrm{R}^{2}$ statistic is calculate for the regression model build, which resulted to be only 0.26 . In addition to analyze reliability of the data a logit model was analyzed, the build model did not bring any improvement, contrariwise the $\mathrm{R}^{2}$ statistic is even lower 0.081 , data shown below.

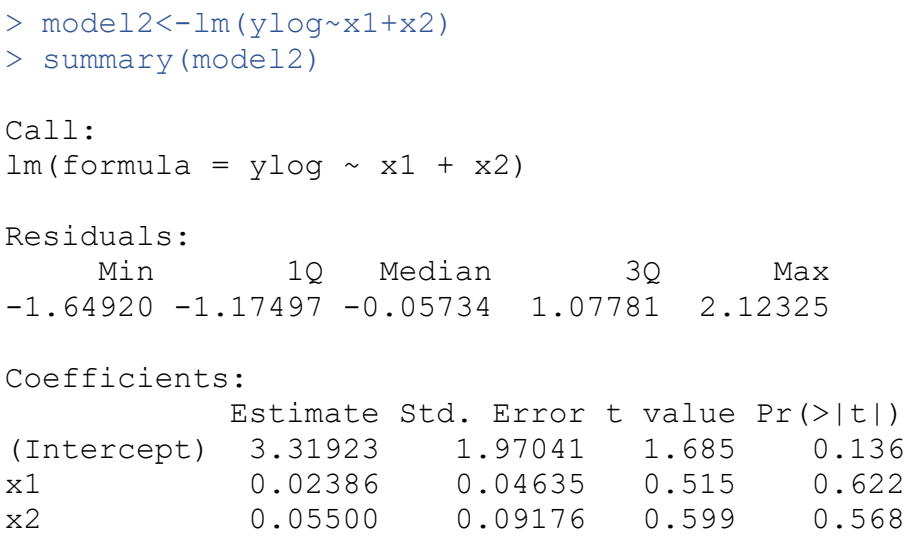

Residual standard error: 1.552 on 7 degrees of freedom

Multiple R-squared: 0.08189, Adjusted R-squared: -0.1804

F-statistic: 0.3122 on 2 and 7 DF, p-value: 0.7415

Moreover, making sure that the best fitting and/or adequate equation model is built for observed data a second order polynomial model is build. First, to build a second order model it is necessary to calculate $x_{1}^{2}, x_{2}^{2}$ and $x_{1} x_{2}$, below are calculated data in Table 3: 
Table 3 Calculated parameters for second order polynomial model and total number of colony form observed data

\begin{tabular}{lllllll}
\hline $\begin{array}{l}\text { No. } \\
\text { experiments }\end{array}$ & $x_{1}$ & $x_{2}$ & $x_{1}^{2}$ & $x_{2}^{2}$ & $x_{1} x_{2}$ & $\begin{array}{l}\text { Total } \\
\text { number } \\
\text { colony } \\
\text { /ml }\end{array}$ \\
\hline $\mathbf{1}$ & & & & & & $\begin{array}{c}\text { of } \\
\mathbf{c f u}\end{array}$ \\
$\mathbf{2}$ & 48 & 4 & 2304 & 16 & 192 & $29 * 10^{2}$ \\
$\mathbf{3}$ & 24 & 4 & 576 & 16 & 96 & $12 * 10^{2}$ \\
$\mathbf{4}$ & 48 & 15 & 2304 & 225 & 720 & $10^{*} 10^{4}$ \\
$\mathbf{5}$ & 24 & 15 & 576 & 225 & 360 & $78^{*} 10^{3}$ \\
$\mathbf{6}$ & 53 & 10 & 2809 & 100 & 530 & $664 * 10^{4}$ \\
$\mathbf{7}$ & 20 & 10 & 400 & 100 & 200 & $446^{*} 10^{3}$ \\
$\mathbf{8}$ & 36 & 20 & 1296 & 400 & 720 & $48^{*} 10^{4}$ \\
$\mathbf{9}$ & 36 & 2 & 1296 & 4 & 72 & $258^{*} 10^{4}$ \\
$\mathbf{1 0}$ & 36 & 10 & 1296 & 100 & 360 & $17 * 10^{2}$ \\
\hline
\end{tabular}

$>\operatorname{mode} 13<-\operatorname{lm}(\mathrm{y} \sim \mathrm{X} 1+\mathrm{X} 2+\mathrm{x} 1 \mathrm{x} 1+\mathrm{x} 2 \times 2+\mathrm{x} 1 \times 2)$

$>\operatorname{summary}(\operatorname{model} 3)$

Call:

$\operatorname{lm}($ formula $=\mathrm{y} \sim \mathrm{x} 1+\mathrm{x} 2+\mathrm{x} 1 \mathrm{x} 1+\mathrm{x} 2 \mathrm{x} 2+\mathrm{x} 1 \mathrm{x} 2)$

Residuals:

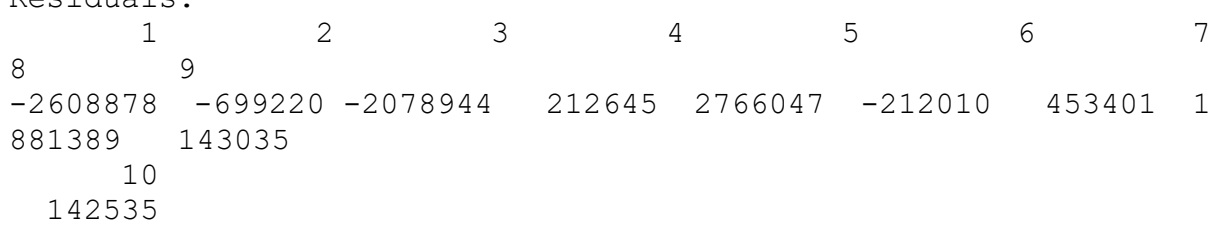

Coefficients:

$\begin{array}{lrrrr} & \text { Estimate } & \text { Std. Error } & \text { value } & \operatorname{Pr}(>|t|) \\ \text { (Intercept) } & 9634265 & 13143189 & 0.733 & 0.504 \\ \text { X1 } & -550787 & 630239 & -0.874 & 0.431 \\ \text { X2 } & -241034 & 885796 & -0.272 & 0.799 \\ \text { x1x1 } & 8671 & 8284 & 1.047 & 0.354 \\ \text { x2x2 } & 6766 & 27720 & 0.244 & 0.819 \\ \text { x1x2 } & 1524 & 18187 & 0.084 & 0.937\end{array}$

Residual standard error: 2405000 on 4 degrees of freedom

Multiple R-squared: 0.4288, Adjusted R-squared: -0.2852

F-statistic: 0.6005 on 5 and 4 DF, p-value: 0.7077

In the same way as showed above are calculated intercept and partial regression coefficients for the second order polynomial model shown in equation $2 . y=963.43 * 10^{4}-550 * 10^{3} x_{1}-$ $241.03 * 10^{3} x_{2}+8671 x_{1}^{2}+6765 x_{2}^{2}+1523 x_{1} x_{2}$

Likewise to the linear regression model, also for the second order model $\mathrm{R}^{2}$ statistic is calculated. A brief enhancement by building secondary order model, $\mathrm{R}^{2}$ statistic resulted to 0.4 which is slightly increase, logit value is analyzed again here but it did not resulted in any improvement the $\mathrm{R}^{2}$ was only 0.37 . 


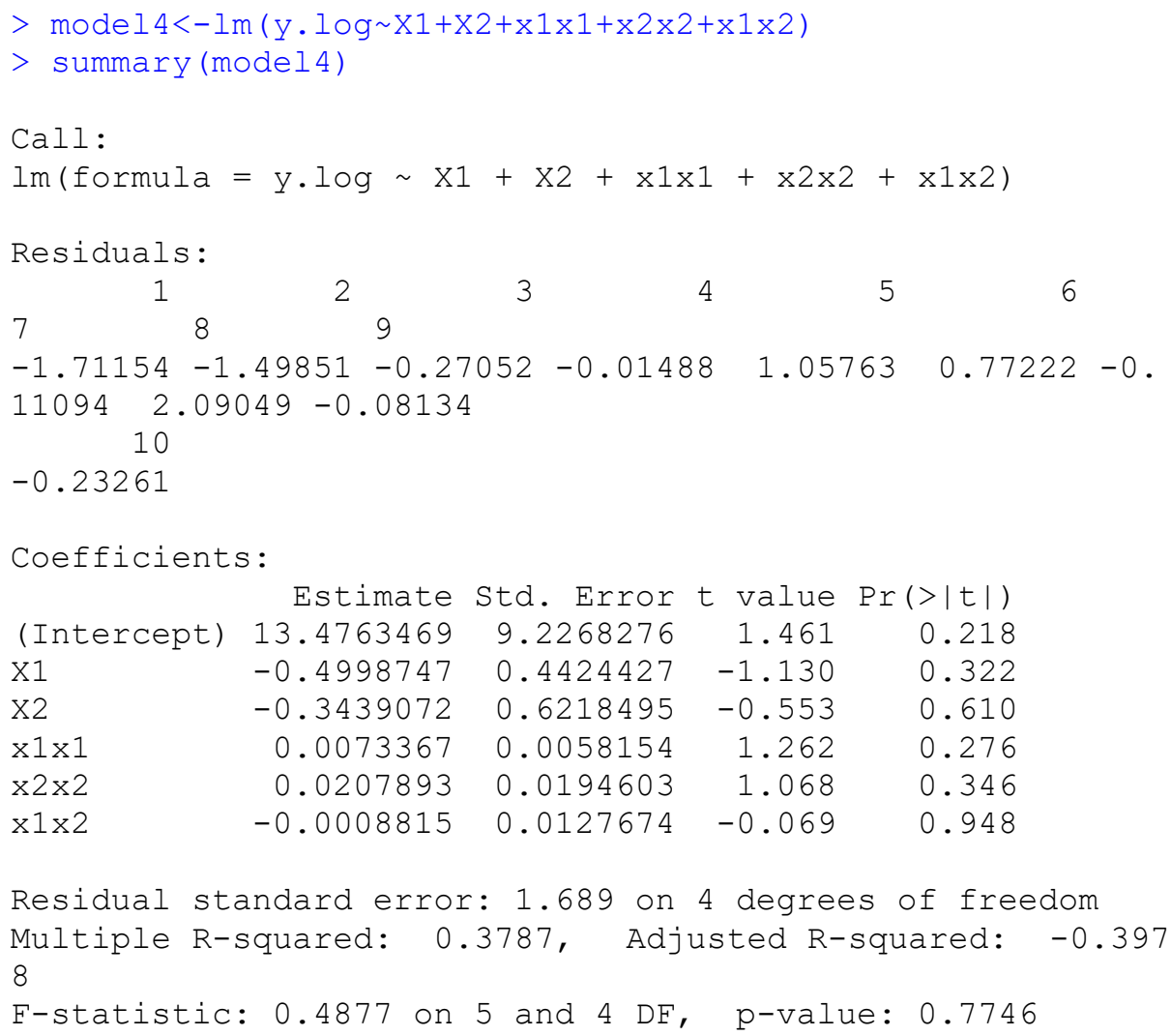

\section{Discussion of the results}

The microbiological analysis performed on the pasteurized milk samples reviled several important information about raw milk quality, hygiene of producing process, safety and shelf life of milk. First, coliform results will be discussed, which presence in milk is considered as indication of low hygiene in farm environment, lacto fridge and/or during the producing process [12]. From ten samples designed with triplicate data, only one sample resulted with presence of coliform, Table 2. Indicating that in general the hygiene of milk production process was acceptable and there was no problem with milk transport hygiene, even though microbiological criteria for coliform bacteria are so strict $[13,14]$, absence of this microorganisms in $25 \mathrm{ml}$ in pasteurized product ready for consummation is required from standard.

On the other hand, for total number of colonies formed in Nutrient Agar the criteria are more tolerant [14] not to exceed $50000 \mathrm{cfu} / \mathrm{ml}$. From ten designed experiments this criteria is not exceeded only by 4 samples, always we should consider that storage conditions are modified based on the design. By using R software two models are prepared based on the observed data. Linear regression model reliability was so low, the $\mathrm{R}$ square statistic resulted only 0.26 . Consequently we cannot relay in this equation to predict the growth of the microorganisms. This model is built only in two independent variable temperature and time while in the work of Obeso et al initial bacterial contamination was as additional parameter which in their case contributed significantly to the first model predication for Staphylococcus growth in pasteurized milk. Moreover, to check for any improvement in the model second order model was used. The build 
model was slightly more reliable than linear model with $\mathrm{R}$ square statistic 0.42 , nevertheless this $\mathrm{R}^{2}$ is not enough for a model this can be noticed in residual data in both linear and second order polynomial model. Additionally, for both linear and second order polynomial a logit analysis was done, but it did not bring any improvement to reliability of the build model. In this case to design a model that can predict the shelf life for pasteurized milk it is necessary to consider other parameters like initial number of microorganisms before the incubation start, which will increase number of designed experiments also. If we analyze the data separately from the designed experiments two first experiments in table 2, storage in temperature that is recomended by producer $4^{\circ} \mathrm{C}$, for both 24 and 48 hours resulted acceptable, colony number formed was less than $50000 \mathrm{cfu} / \mathrm{ml}$ requested by standard for pasteurized milk. Interestingly, the sample that was stored at $2^{\circ} \mathrm{C}$ for which was expected to have less number of microorganisms grown resulted with a high number of microorganisms, this prove that initial number of microorganisms is necessary.

\section{CONCLUSIONS}

In the present study, RSM methodology was used to design experiments for pasteurized milk analyzing for total colony formed and total coliform isolation. Temperature and time were used as independents factor during the incubation, form results by using $\mathrm{R}$ software two models linear and second order are built to predict total number of colony formed. Both built models resulted unreliable to predict growth the residual was so high. Therefore, based on the results and literature, to build a reliable model is necessary to add as independent parameter the initial number of microorganisms and to increase the number of experiments designed.

Acknowledgments. The authors would like to acknowledge Department of Food Technology and Engineering at University of Mitrovica for providing facilities for this project.

\section{REFERENCES}

.Vahedi, M., et al., Bacteriological study of raw and unexpired pasteurized cow's milk collected at the dairy farms and super markets in Sari city in 2011. J Prev Med Hyg, 2013. 54(2): p. 1203.

2. Boitz, L.I. and H.K. Mayer, Extended shelf life milk - One concept, different qualities: A comprehensive study on the heat load of differently processed liquid milk retailed in Austria in 2012 and 2015. LWT - Food Science and Technology, 2017. 79: p. 384-393.

3. Doll, E.V., S. Scherer, and M. Wenning, Spoilage of Microfiltered and Pasteurized Extended Shelf Life Milk Is Mainly Induced by Psychrotolerant Spore-Forming Bacteria that often Originate from Recontamination. Front Microbiol, 2017. 8: p. 135.

4. Ranieri, M.L., et al., Real-time PCR detection of Paenibacillus spp. in raw milk to predict shelf life performance of pasteurized fluid milk products. Appl Environ Microbiol, 2012. 78(16): p. 5855-63.

5. Garedew, L., et al., Identification of gram-negative bacteria from critical control points of raw and pasteurized cow milk consumed at Gondar town and its suburbs, Ethiopia. BMC Public Health, 2012. 12: p. 950.

6. Anderson, M., et al., The microbial content of unexpired pasteurized milk from selected supermarkets in a developing country. Asian Pac J Trop Biomed, 2011. 1(3): p. 20511.

7. Saleh-Lakha, S., et al., A Study To Assess the Numbers and Prevalence of Bacillus cereus and Its Toxins in Pasteurized Fluid Milk. J Food Prot, 2017. 80(7): p. 1085-1089. 
8. Koutsoumanis, K., et al., Probabilistic model for Listeria monocytogenes growth during distribution, retail storage, and domestic storage of pasteurized milk. Appl Environ Microbiol, 2010. 76(7): p. 2181-91.

9. Xanthiakos, K., et al., Dynamic modeling of Listeria monocytogenes growth in pasteurized milk. J Appl Microbiol, 2006. 100(6): p. 1289-98.

10. 1Raymond, H.M., C.M. douglas, and M.A. Christine, Response surface methodology process and product optimization using designed experiments. Fourth edition ed, ed. N.A.C.C. David J. Balding, Garrett M. Fitzmaurice,, H.G. Geof H. Givens, Geert Molenberghs, David W. Scott,, and R.S.T. Adrian F. M. Smith, SanfordWeisberg. 2016, United States of America: Wiley. 855.

11. Silva, N., et al., Microbiological examination methods of food and water ed. N. Silva, et al. 2013, Netherland: CRC Press. 469.

12. Wanjala, G., Microbiological quality and safety of raw and pasteurized milk marketed in and around Nairobi region. African Journal of Food, Agriculture, Nutrition and Developement, 2017. 17(01): p. 11518-11532.

13. Kosovo, G.o.t.R.o., Microbiological criteria for food stuffs, O.o.t.P. Minister, Editor. 2011, Office of the Prime Minister: Republic of Kosovo.

14. Critera, F.A.M.M., Microbiological Reference criteria for food, M.o. Health, Editor. 1995. 